\title{
REFLEKSI AKSIOLOGIS ATAS TEORI BAHASA NOAM CHOMSKY DAN M.A.K HALLIDAY
}

\author{
Paulus Kurnianta ${ }^{1)}$ dan Septiana Dwiputri Maharani ${ }^{2)}$ \\ ${ }^{1)}$ Universitas Negeri Yogyakarta dan ${ }^{2}$ Universitas Gadjah Mada \\ Email: paulkurnianta@gmail.com
}

\begin{abstract}
(Title: Axiological Reflections on Noam Chomsky's and M.A.K Halliday's Language Theories). This article is meant to philosophically reflect Chomsky's and Halliday's language theories by focusing on the axiological dimension of their theoretical constructs, that is, what are the hidden values therein. To draw basic sketches of their theoretical constructs, their ontological and epistemological assumption are explored. Furthermore, Gruenberg's axiological scheme is adopted to discuss them. From the chains of reflection, it is found that in Chomsky's the positive pole of human-language relation exists in language with internal, mental, logical-objective, formal, neutral, innate, certain, transparent, stable, alogarithmic and closed or un-contextual characteristics. The superior language is scientific, positivistic and logical language. Meanwhile, in Halliday's the positive pole exists in language with practical, external, semiotical, social, cultural, participatory, concrete, critical, dynamic, discursive, authentic, interpretative and open or contextual. The superior language is authentic language which is rich of signification.
\end{abstract}

Key words: axiology, language theory, Chomsky, Halliday

\section{PENDAHULUAN}

Meskipun filsafat bahasa dan ilmu bahasa baru meramaikan dunia filsafat di abad ke-20, pemikiran tentang bahasa dalam sejarah FilsafatBaratsudah dimulai sejakjaman Yunani. Bukti mengenai pemikiran itu dapat ditemukan dalam dialog Plato, Cratylus, dimana ada dua tokoh yang berdebat di hadapan Socrates. Persoalan mendasar yang mengemuka adalah apakah bahasa muncul secara alamiah ataukah bahasa lahir karena konvensi (Kaelan, 2017: 28). Dua tokoh dalam dialog itu menyuguhkan dua tesis yang berseberangan mengenai asalmuasal bahasa; Cratylus berpangkal pada fisei sementaraHermogenes pada nomos. Perdebatan semacam itu bahkan terulang lagi dalam teori bahasa modern sebagaimana ditampilkan oleh Noam Chomsky dan M.A.K. Halliday.

Konstruksi teoritis manakah yang akan diikuti dan mengapa demikian ? Pendekatan filososfis dapat diambil sebagai alternatif untuk melakukan refleksi teoritis. Filsafat nilai atau aksiologi $($ axios $=$ nilai; $\operatorname{logos}=$ pengetahuan $)$ adalah cabang filsafat yang mendiskusikan persoalan nilai secara umum. Namun demikian, secara khusus aksiologi dapat dipakai untuk menilik nilai dari sebuah konstruk teoritis.
Selama ini beragam teori sibuk merumuskan isi pengetahuan namun lupa memperbincangkan nilai dari pengetahuan yang telah dirumuskannya.

Dalam sejarah, Aristoteles mencoba melakukan refleksi atas pemikiran Cratylus dan Hermogenes. Cratylus bersikukuh bahwa bahasa bersifat alamiah (fisei). Argumennya adalah bahwa dibalik bahasa ada prinsip-prinsip yang bersifat abadi yang keberadaannya tidak tergantung pada manusia. Contoh yang diambil untuk membuktikan argumen ini adalah fonim atau bunyi bahasa. Di balik bunyi bahasa yang terkesan biasa-biasa saja, ada komposisi bunyi yang berelasi langsung dengan benda yang diacu di dunia. Misalnya bunyi embek dan meong masing-masing mengacu pada kambing dan kucing. Sementara itu, Hermogenes tidak mau kalah. Prinsip onomatopoeia yang diajukan Cratylus, sebagai salah satu lacakan asal-usul bunyi, hanya menjelaskan sebagian kecil asal-usul kata. Bila argumen itu benar, semua orang di muka bumi akan menggunakan kata embek dan meong untuk mengacu pada binatang yang sama. Kenyataannya tidak demikian karena setiap bahasa mempunyai kebiasaan masing-masing dan tampak jelas 
pada leksikon yang berbeda-beda meskipun mengacu pada referensi yang sama. Karena itu, bahasa bersifat konvensional (nomos).

Refleksi Aristoteles atas perdebatan CratylusversusHermogenesterdokumantasikan dalam deInterpretationete. MenurutAristoteles, baik prinsip fisei (naturalisme) maupun nomos (konvensionalisme) sama-sama memberikan sumbangan, masing-masing terhadap aspek referensial bahasa dan aspek kolektif-evolutif bahasa. Naturalism is shown to be required in order to give adequate account of truth; conventionalism, however, is shown to provide a more satisfactory account in the way in which the words of a natural language acquire, maintain and change meanings (Modrak, 2001: 4). Refleksi Aristoteles ini berkisar pada apa sumbangan pemikiran keduanya terhadap teori bahasa yang akan dikembangkan oleh Aristoteles sendiri. Aristoteles kemudian memposisikan bahasa sebagai medium yang netral dan transparan, yang ideal untuk ilmu pengetahuan.

Menurut Grunberg (2000:126), aksiologi memiliki arah refleksi yang berbeda. Bila Aristoteles berpangkal pada ilmu pengetahuan sebagai proyek utama filsafatnya sehingga teorinya tentang bahasa mengabdi pada obyektifisme, aksiologi mengedepankan persoalan nilai yaitu sejauh mana sebuah teori bermakna bagi manuasia. Selama ini aksiologi adalah cabang filsafat yang terpinggirkan di paruh kedua abad ke-20 karena modernisme secara meyakinkan telah memberikan jawabanjawaban atas persoalan-persoalan manusia melalui sains dan ilmu-ilmu yang bersifat obyektif dan positivistik. Namun kini normanorma positivisme bukan lagi pondasi tunggal yang mampu menyelesaikan krisis manusia moderrn. Positivisme bukan satu-satunya paradigma pengetahuan. Konsekuensinya, muncul beragam teori atas obyek yang sama namun kadang berseberangan seperti teori bahasa yang ditampilkan oleh Chomsky dan Halliday.

Dalam sejarah filsafat Barat perbincangan mengenai mengenai bahasa sudah dimulai sejak awal hingga kini. Fakta ini menunjukkan bahwa bahasa adalah bagian penting dari pemikiran itu sendiri. Dalam perkembangannya ada disiplin keilmuan yang juga memperbincangkan bahasa, yaitu linguistik dan filsafat bahasa dan keduannya baru ramai diperbincangakan di abad ke-20. Mendiskusikanteoribahasa secarafilosofis tidak selalu dapat diterima dan sebaliknya. Filsafat menuduh bahwa linguistik mencari jawaban atas pertanyaan-pertanyaan fundamental tentang bahasa dengan mengais kata-kata dan menetapkan hukum-hukumnya. Sementara linguistik melecehkan filsafat dengan tuduhan bahwa filsafat memberikan jawaban atas persoalan empiris dengan bersembunyi di balik meja. Apakah linguistik tampil sebagai rival filsafat dalam menjawab pertanyaanpertanyaan seputar bahasa? Menurut Peregrin (2012: 1-2), filsafat dan linguistik tidak perlu dipertentangkan sebagai pihak yang paling berhak berbicara tentang bahasa.

Peregrin justru mengajukan tesis bahwa keduanya saling melengkapi karena linguistik berasal dari tulang rusuk filsafat. Bedanya, filsafat memulai dengan pertanyaanpertanyaan fundamental dan menjawabnya dengan argumen koseptual-teoritis sedangkan linguistik menjawab pertanyaan-pertanyaan itu dengan metode ilmiah dan data empirik. Bila bahasa adalah sebuah hutan belantara untuk dijelajahi, filsafat terbang di atasnya dan memberikan gambaran global tentang hutan, semantara linguistik akan menggambarkannya secara mendetail seperti seorang petualang. Bukankah keduanya saling melengkapi untuk memberikan gambaran yang utuh mengenai hutan tersebut?

Dalam kajian ini, akan diketengahkan dua pemikir besar teori linguistik yang mempunyai banyak pengikut dan masih berkembang hingga kini, yaitu Noam Chomsky dan M.A.K. Halliday. Corak pemikiran mereka berbeda, bahkan bisa dikatakan berseberangan. Penulis akan membuat refleksi aksiologis atas garis besar pemikiran Chomsky dan Halliday.

Kajian nilai ini dilakukan terhadap konseptualisasi mereka mengenai bahasa yang tersaji dalam Language and Mind (Chomsky) dan Language as Social Semiotics (Halliday). 


\section{METODE}

Kajian atas dua corak pemikiran bahasa, yaitu Halliday dan Chomsky, bersifat filosofis. Dalam penelitian filsafat, kajian seperti ini dimodelkan sebagai penelitian mengenai pemikiran atau teori ilmiah (Bakker dan Zubair, 1990: 114-120). Tujuannya adalah untuk secara kritis mengevaluasi pemikiran Chomsky dan Halliday dengan menemukan filsafat-tersembunyi mereka mengenai bahasa. Untuk melakukan evaluasi kritis tersebut penulis membuat rangkaian asumsi teoritisfilosofis berupa konstruksi ontologis, epistemologis dan aksiologis. Bangunan asumsi tersebut akan membantu penulis mendekati persoalan yang diajukan dan memberikan jawabannya.

Dimensi aksiologis dari sebuah pemikiran tidak mungkin terkonstruksikan tanpa mempertimbangkan dua hal yang sangat penting dalam sebuah pemikiran yaitu dimensi ontologis dan dimensi epistemologis. Dimensi ontologis mengacu pada hakikat ada bahasa. Pijakan ini akan membantu penulis membuat sketsa pemikiran masing-masing tokoh. Dimensi epistemologis mengacu pada posisi subjek-objek pengetahuan yang akan menghasilkan konstruk teoritis tertentu.

Setelah mendapatkan sketsa pemikiran tentang hakikat bahasa dan konstruk teoritis bahasa, peneliti akan merekonstruksi nilai dari pemikiran yang sudah dirumuskan oleh masingmasing tokoh. Kajian atas apa nilai pengetahuan dari kontruk teoritis atau konseptuaisasi mereka tentang bahasa memiliki keuntungan aksiologis (Peregrin, 2012:202), yaitu pemahaman yang bersifat reflektif. Adapun teori aksiologi yang diambil sebagai kerangka teoritis refleksi ini adalah teori nilai Grunberg.

\section{PEMBAHASAN}

Konstruk Ontologis

Hakekat Bahasa dalam Pemikiran Chomsky

Dalam Language and Mind (2006:88), Chomsky menegaskan bahwa when we study human language, we are approaching what one might call the "human essence," the distinctive qualities of mind that are, so far as we know, unique to man...berbicara tentang bahasa adalah berbicara tentang hakikat manusia yaitu pikiran. Pikiran merupakan aspek mental yang berasal organ otak sebagai situs bagi ide bawaan (innate ideas). Selanjutnya konsepsi tentang bahasa sangat erat dikaitkan dengan kapasitas berbahasa sebagai kapasitas berpikir (language faculty).

Kemudian apakah hakikat bahasa menurut Chomsky? Hakekat bahasa adalah pikiran yang dirumuskan sebagai Universal Grammar (UG). UG bukanlah bahasa lisan ataupun bahasa tertulis ataupun teori tata bahasa namun UG merupakan underlying principles atau prinsip-prinsip dasar yang ada dibalik bahasa. Prinsip-prinsip dasar ini hadir dalam wujud competence atau kemampuan manusia untuk berbahas dan mamahaminya, yang bermatra batin dan tak disadari (unconscious). Sementara praktek bahasa, lisan dan tulisan, mewujud dalam performance yang berdimensi lahiriah dan disadari. Competence tersebut paralel dengan deep structure atau struktur dalam/prinsip struktur. Sementara itu, performance paralel dengan surface structure yaitu bahasa yang secara empiris digunakan sehari-hari.

Fokus kajian linguistik adalah competence sehingga linguistik sebagai ilmu bahasa perperan untuk menemukan prinsipprinsip UG: tha most challanging theoretical problem in linguistics is that of discovering the principles of universal grammar which interwaave with the rule of particular grammar to provide explanation for the phenomena that appear arbitrary and chaotic (Chomsky, 2006: 42). Untuk membedakannya Chomsky menggunakan dua istilah, yaitu principle dan rule. Rule mengacu pada aturan bahasa atau gramatika yang selama ini menjadi obyek kajian traditional grammarian, sementara principle adalah kapasitas dalam pikiran manusia yang secara istimewa mampu mengerti rule tadi sebagai sistem simbolik-logis dalam bahasa manusia.

Prinsip-prinsip tersebut serupa hukum yang pasti dan ada di semua bahasa manusia baik bahasa primitif maupun modern. Bahasa disejajarkan dengan logika modern dan rumus matematik yang bersifat pasti dan berlaku universal. Misalnya, John is to leave is certain dapat dirumuskan secara algoritmik ke dalam 
[S[NP[S[NP][VP]]][VP[AP]]]. Rumusan alogaritmik (logis dan sistematis) seperti inilah yang kemudian dapat diadopsi sebagai sistem kode dalam program komputer sehingga komputer mampu menerjemahkan bahasa manapun sejauh inputnya ada dan mengikuti kode alogaritmik tersebut.

UG bukan sesuatu yang kita pelajari di kelas; ia ada di dalam diri manusia sebagai innate ideas yang berlaku universal. Chomsky juga menyebutnya language faculty yang berdimensi internal atau disebut Internal Language (I-Language). Model pemahaman bahasa seperti ini dapat menjelaskan mengapa setiap anak mampu berbahasa-ibu tanpa mempelajarinya secara formal dan mengapa setiap manusia dengan latar belakang bahasa apapun dapat mengerti dan menggunakan bahasa sebagai sistem simbol.

\section{Hakekat Bahasa dalam Pemikiran Halliday}

Dalam Language as Social Semiotics Halliday berpendapat bahwa bahasa adalah realitas sosial dan realitas sosial adalah bangunan makna atau konstruk semiotis yang terbentuk melalui interaksi atau praksis komunikasi. Bangunan makna atau konstruk semiotik atau sistem semantis mengodekan dua aspek fundamental bahasa yaitu bahasa sebagai alat untuk merefleksikan sesuatu (ideational) dan sebagai alat untuk bertindak/berinteraksi (interpersonal). Dalam sistem semantis, bahasa sebagai alat refleksi adalah komponen ideasional makna dan bahasa sebagai alat interaksi adalah komponen interpersonal makna.

Dimensi ideasional dan interpersonal ini adalah realitas simbolik fungsi bahasa sehingga tidak dapat ditemukan secara langsung dalam bahasa sehari-hari. Dapat dikatakan bahasa adalah salah satu sistem semiotik yang ikut membentuk kebudayaan sebagai bangunan makna. Bahasa lisan dan tulis dalam realitas empiris lebih dekat dengan dimensi tekstual (textual) karena menunjukkan fungsi yang secara intrinsik ada di dalam bahasa sementara dua fungsi sebelumnya menunjuk fungsi yang secara ekstrinsik ada di luar bahasa. komponen ideasional-interpersoanal-tekstual berfungsi sebagai sistem triadik kebahasaan pada level semantik: I have used triadic system in my own work with ideational, interpersonal and textual components...that the language system is infact trimodal at its semantic level (1978:3)

Lebih jauh, bahasa sebagai alat refleksi dan aksi harus selalu dimengerti secara semiotik, bukan bahasa sebagai alat untuk mengekspresikan sistem sosial atau hirarki sosial secara lnagsung, tetapi bahasa sebagai sistem penandaan untuk menyimbolkan sistem sosial atau hirarki sosial. Dengan demikian relasinya terjadi dalam penandaan, tidak secara langsung. Halliday menggunakan sebuah metafor atau istilah "metafungsi" (metafunction) untuk fungsi penandaan semiotis dalam bahasa: a language which is still functional in origin but whre the concept of "function" has undergone a significant change: it is no longer synonymous with "use," but has becomes much more abstract, a kind of metafuction through which all the numerable concrete uses...are given symbolic expression in a systematic and finite form (1978:22). Istilah metafungsi ini memperdalam arti use, atau penggunaan bahasa; bahasa bukan sekedar alat, lebih dalam lagi, bahasa merupakan ekspresi simbolik. Ekspresi simbolik ini tidak bersifat serampangan namun memiliki suatu bentuk yang sistematis dan jelas. Sebuah peristiwa yang sama dapat terumuskan oleh seseorang atau pihak tertentu secara berbedabeda tergantung pada konteks sosio-politiskultural yang menyediakan kemungkinan pilihan-pilihan makna (meaning resources). Misalnya, headline di surat kabar tentang pencalonan Gibran sebagai walikota mungkin direalisasikan dalam beberapa judul: Anak Jokowi Berpolitik, Gibran Mendaftarkan diri sebagai Walikota, atau Anak Presiden Mengadu Peruntungan dalam Politik dan seterusnya. Rumusan tertentu akan membawa tafsir dan dampak tertentu dan juga pesan kebenaran tertentu tergantung pada meaning resources yang dimainkan.

Hakikat bahasa ada pada dimensi fungsionalnya dan dimensi ini adalah fungsi simbolik yang secara bersamaan ditemukan pada penandaan internal bahasa dan penandaan eksternal bahasa sekaligus. Dengan demikian bahasa sebagai sistem linguistik dapat dikaitkan 
dengan konteks sosialnya namun tetap merupakan sebuah kesatuan dimensi internal dan eksternal. Bahasa empiris lisan dan tulisan adalah ekpresi (expression) yang merupakan materi mentah. Lensa metafungsi dapat memperjelas materi mentah itu sebagai jalinan penandaan yang rumit. Kerumitan penandaan itu dapat diuraikan melalui triadik metafungsi tadi. Fungsi ideasional mengkodekan relasi referensial. Fungsi interpersonal mengkodekan relasi sosial. Fungsi tekstual mengkodekan realisasi bentuk linguistik. Sekali lagi, fungsi pertama dan kedua adalah dimensi eksternal linguistik sementara fungsi ketiga adalah dimensi internal linguistik. Kutub internaleksternal merupakan pembagian fungsi penandaan dalam bahasa sehingga tidak terpisah-pisah. Ketiganya saling mendukung dalam menginterpretasi bahasa.

Fungsi ideasional adalah pengkodeaan bahasa atas pengalaman manusia terhadap dunia (field) yang dapat dicermati pada transitivitas (transitivity). Fungsi interpersonal adalah pengkodean bahasa atas relasi sosial para partisipan (tenor) yang dapat dicermati pada suasana (mood). Fungsi tekstual pada pengkodean bahasa atas informasi yang dipentingkan (mode) yang dapat dicermati pada tema (theme).

Kemudian, pada level analisis linguistik, transitivitas berfokus pada kata kerja, yang dimengerti sebagai kode refleksi atas pengalaman terhadap dunia; mood berfokus pada relasi sosial yaitu bagaimana suasana para pelaku dalam interaksi apakah mencerminkan status yang sejajar ataukah asimetris; sementara, tema berfokus pada bagaimanakah informasi ditata dalam kalimat, yaitu, informasi manakah yang dipentingkan dan informasi manakah yang dipinggirkan.

Dengan demikian dapat dipahami bahwa bahasa adalah sistem penandaan yang berlapis-lapis. Bahasa lisan dan tulis yang empiris memuat tiga lapis penandaan. Penandaan pertama berupa sistem gramatika fungsional yang dinamakan lexico grammar dengan komponen transitivitas, mood dan tema. Lapis kedua adalah sistem semantik fungsional dengan komponen maknaideasional, interpersonal dan tekstual. Lapis ketiga adalah konteks sosial dengan komponen field, tenor dan mode. Lapis-lapis penandaan inilah yang menghubungkan bahasa empiris dan konteks sosialnya.

\section{Konstruk Epistemologis}

Gallagher (Hardono, 1994: 13-17) berpendapat bahwa epistemologi adalah pertanyaan relflektif yang mendasar mengenai pengetahuan:apakahiamerupakan pengetahuan yang sejati atau sekedar ilusi, pengetahuan palsu. Pertanyaan ini selalu muncul karena manusia merupakan makhluk yang mendua: terkait dengan temporalitas terdapat keabadian dan kesementaraan, terkait dengan realitas terdapat pikiran dan pengalaman, terkait dengan eksistensi terdapat diri dan bukan diri. Konsekuensinya, kemenduaan itu memerangkap manusia untuk selalu meragukan kebenaran. Bentuk konsekuensi lain adalah munculnya teori-teori yang berbeda atas obyek kajian yang sama, yang kemudian kita kenal dengan aliran (schools). Persoalannya, bila berbeda, bagaimana mereka berbicara soal kebenaran? Apakahbenaryang diperbincangkan adalah kebenaran atau sekedar keyakinan?

Bila pengetahuan dipahami sebagai justified true belief atau keyakinan yang terbukti benar maka pengertian dari bukti dan kebenaran harus dicermati dengan teliti. Bukti disyaratkan untuk memberikan kepastian akan kebenaran dan kebenaran yang dimaksud adalah kebenaran epistemologis (Hardono, 1991). Ambivalensi manusia sebagai subjek pengatahuan dihadapkan pada (1) persoalan objek pengetahuan: apakah dia berhadapan dengan kesan atau kenyataan dan (2) persoalan kebenaran: bila kebenaran adalah kesesuaian pikiran dan kenyataan apakah subjek harus bersikap netral atau boleh menjadi partisipan. Gabriel Marcel merespon persoalan ini dengan membedakan dua jenis pengetahuan (1) pengetahuan inderawi dimana subjeknya adalah subjek transendental yang netral dan objek pengetahuannya berupa kenyataan dan (2) pengetahuan intelektual dimana subjeknya adalah subjek partisipatif dan objek pengetahuannya berupa kesan sebagai hasil interaksi subjek partisipatif terhadap objek. 
Kerangka epistemologis dengan tegangan subjek-objek sebagai teori tentang pengetahuan ini, setidaknya dapat menjadi pijakan pemahaman untuk melihat teori-teori yang muncul dalam beragam bidang ilmu, termasuk bahasa. Dari kerangka epistemologis tersebut dapat disusun seperangkat pertanyaan sebagai berikut untuk melihat konstruk teoritis Chomsky dan Halliday: 1) apakah formulasi bahasa sebagai kenyataan dalam teori mereka, 2) siapakah subyek pengetahuan dan bagaimanakah posisi subyek pengetahuan: berlaku sebagai subyek transendental atau subyek partisipatif, 3) apakah isi pengetahuan yang ditampilkan dalam teori bahasa masingmasing, dan 4) Sejauh mana masing-masing teori terbuka terhadap realitas bahasa secara utuh?

Selanjutnya, untuk menjawab pertanyaan di atas penulis mengacu pada hakikat bahasa yang sudah dibahas sebelumnya. Pertama, dalam gagasan Chomsky realitas bahasa yang menjadi objek linguistik adalah competence atau I-Language, bukan performance atau E-Language. Sementara itu dalam gagasan Halliday objek linguistik adalah praksis penandaan bahasa, bukan aspek internal bahasa per se. Kedua, bagi Chomsky subjek pengatahuan adalah subjek transendental dengan kapasitas bawaan yang menemukan rumus bahasa, sedangkan bagi Halliday subjek pengetahuan adalah subyek sosial yang berperan menafsirkan bahasa. Ketiga, isi pengetahuan versi Chomsky adalah UG, satu hukum bahasa yang berlaku tetap untuk semua bahasa, sedangkan versi Halliday adalah metafungsi, bahasa sebagai sistem penandaan yang mengakomodasi keragaman. Keempat, realitas bahasa yang diambil oleh Chomsky adalah bahasa yang sesuai dengan prinsip logis-alogaritmis. Sementara itu, realitas bahasa yang diambil Halliday adalah bahasa sebagai peristiwa komunikatif yang bersifat interpretatif.

Berdasarkan pemahaman tersebut konstruk teoritis mereka tentang bahasa dapat digambarkan secara lebih jelas. Dalam teori Chomsky, subjek rasional dengan kapasitas bawaan dapat memahami hukum universal bahasa. Rumusan bahasa bahasa ada satu dan bersifat tetap dan berlaku universal. Bahasa adalah sains. Bukti dari kebenaran itu adalah UG. Dalam teori Halliday sebyek pengetahuan adalah subyek yang memaknai. Bahasa merupakan penandaan yang berlangsung dari level linguistik hingga konteks sosial. Bukti kebenaran itu adalah metafungsi. Bahasa adalah semiotika.

\section{Refleksi Aksiologis \\ Keterkaitan antara Nilai dan Konstruk Teoritis}

Hugh (2004: xi-xiv) secara kritis mengomentari surutnya perbincangan tentang nilai terutama di paruh kedua abad ke-20. Baru di abad ke 21 ini teori nilai kembali mengemuka. Ia menenggarai bahwa posisi ini disebabkan warisan pemikiran Aristoteles yang memposisikan filsafat sebagai pembantu atau pelayan (handmaiden) ilmu pengetahuan. Sebelumnya, Socrates tidak memisahkan wisdom dan life, kebijakan atau pengetahuan adalah sebuah keutuhan, sementara Aristoteles mengabstraksikan kehidupan menjadi bentuk pengetahuan. Bila di abad pertengahan majikannya adalah Tuhan, di abad ke-20 majikan baru itu bernama Sains. Baru di abad ke-21, timbul kesadaran kritis bahwa sains terlalu otoriter menyatakan dirinya bebas nilai. Seolah-olah paradigma modernisme dengan sains sebagai modelnya tak perlu bertanggungjawab atas beragam krisis seperti pemanasan global yang terus berlari, nuklir yang masih diandalkan sebagai energi alternatif dan teknologi pertahanan, rekayasa genetika seperti genome/gen editing untuk manusia. Pada dataran kesadaran ini, muncul pertanyaan apakah benar pengetahuan bebas nilai bersifat netral?

Terkait dengan pertanyaan itu, Grunberg (2000:17) secara tegas menyatakan: Axiological temperature never read zero. Apapun bentuknya, pengetahuan tidak pernah dapat menghindar dari persoalan nilai, yaitu sejauh mana pengetahuan bermakna bagi manusia (human significance), bukan sekedar bermanfaat/berguna karena manfaat hanya salah satu bentuk nilai. Nilai (value) sangat luas, seluas cakupan kehidupan manusia itu sendiri dan dalam kehidupan manusia selalu 
dihadapkan pada soal penilaian (judgment, appreciation, consideration, valuation). Kvanvig (2003: 192-193) menggunakan istilah knowledge dan understanding untuk mempertegas perbedaan antara pengetahuan (knowledge) dan pemahaman (understanding). Kerangka pemikiran ini akan digunakan untuk memperjelas dimensi aksiologis pemikiran Chomsky dan Halliday mengenai bahasa.

Terkait dengan teori nilai, persoalan selajutnya adalah apakah nilai memiliki realitasnya sendiri: bukankah nilai selalu merupakan nilai dari/akan sesuatu, kalau demikian teori tentang nilai tidak pernah memiliki objeknya sendiri karena nilai itu sendiri bersifat parasitis? Menanggapi pertanyaan tentang realitas nilai ini, Grunberg berpendapat bahwa nilai memang memiliki carrier sehingga selama ini nilai cenderung dipredikasikan pada objek. Ia menggeser nilai yang semula berdiam pada obyek ke "relasi" subjek-objek. Dengan demikian, Nilai adalah relasi antara subjek yang menilai dan objek yang bernilai. Relasi inilah yang merupakan realitas nilai (realm of value). Dengan demikian, aksiologi sebagai filsafat nilai mempunyai objek kajiannya sendiri, yaitu realitas nilai.

Aksiologi sebelumnya berfokus pada tiga nilai dasar klasik (basic values), yaitu, baik-indah-benar (good, beautiful and true). Ada kesulitan mendasar, misalnya, ketika kriteria kebenaran digunakan sebagai patokan karena kebenaran tidak menganut hirarki tetapi kemutlakan. Karena itu Grunberg menawarkan pendakatan baru: axiology acquires new attributes, becoming not only antropocentric but also axiocentric (2000: 109). Pendekatan ini juga dinamakan axiocentric ontology, yang berbeda dari anthropocentric ontology. Pusat filsafat tidak melulu dipusatkan pada subjek dimana subjek transendental sangat dominan, namun lebih pada dunia pemaknaan dimana subjek partisipatif terlibat dalam relasi. Pendekatan baru lebih sesuai karena tatanan nilai dalam kehidupan bersifat majemuk (polyphonic values).

Kemudian, bagaimanakah kerangka teori nilai ini diacu sebagai tinjauan atas pemikiran Chomsky dan Halliday? Bukankah konstruk teoritis yang mereka hasilkan memang sudah menunjukkan perbedaan? Nilai berlaku umum (generic value) dan berada dalam satu dunia yang sama yaitu realitas nilai sehingga nilai merupakan rekonstruksi atas apa saja yang kita alami secara fundamental sebagai manusia. Dengan semikian meskipun corak pemikiran mereka berbeda tetaplah sah untuk ditinjau secara aksiologis.

Kalaupun kemajemukan nilai dapat diterima, lantas apa yang dapat digunakan sebagai dasar penilaian? Ada dua acuan yaitu polarity of value dan hierarchy of value. Polaritas nilai, yaitu kutub positif-negatif (disapproval-disapproval) dan hierarki nilai, yaitu derajat tinggi-rendah (superior-inferior), merupakan faktor utama penentu relasi nilai (primary relational determinants of value). Dengan demikian yang menjadi kajian bukan manusia per se atau bahasa per se namun relasi antara manusia dan bahasa dalam kaitan yang lebih luas yaitu berbahasa sebagai pengalaman manusia. Kalau demikian, refleksi aksiologis dapat dilakukan terhadap konstruk teoritis Chomsky maupun Halliday.

\section{Refleksi Nilai dalam Konstruk Teoritis Chomsky}

Selanjutnya refleksi nilai ini dapat dilakukan pertama dengan menilik relasi subjek pengetahuan terhadap hakekat bahasa. Bahasa adalah I-Language. Letak bahasa tidak berada di luar bahasa itu sendiri namun ada di dalam bahasa. Yang ada di dalam bahasa bukan struktur gramatika namun struktur logis bahasa. Bentuk struktur logis ini mempunyai kesesuaian dangan dengan struktur logis yang ada di dalam struktur kognitif manusia yang disebut dengan language faculty. Dengan demikian hanya ada satu struktur logis yang sama persis. Bila hakekat bahasa seperti ini dihadapkan dengan bahasa sebagai keseluruhan pangalaman manusia, maka aspek hakiki bahasa Chomsky secara spesifik mencakup strukturdalam dari bahasa yang bersifat formal logis. Polaritas kutub nilai positif terletak pada kutub kognitif objektif dan secara hierarkis bahasa yang superior adalah bahasa yang memiliki sifat formal, logis dan objektif sebagaimana dapat ditemukan dalam struktur mental atau pikiran manusia. 
Kedua adalah relasi subjek terhadap posisinya dalam menteorikan bahasa. Subjek adalah sang pengamat transendental yang mengamati bahasa. Subjek transendental ini tidak menciptakan struktur logis bahasa tetapi menemukannya karenakemampuan memahami bahasa yang seperti itu sudah merupakan ide bawaan. Dengan demikian subjek bersikap netral karena ciri logis bahasa itu sudah ada sebagai endowment. Jadi subjek ada pada kutub netral-objektif bukan sebagai partisipan. Secara hierarkis, bahasa yang ungul adalah bahasa objektif yang melepaskan diri dari penilaian subyek, sehingga bahasa tersebut mampu mereprensatasikan dunia secara transparan dan pasti.

Ketiga, relasi subyek terhadap isi pengetahuan. Isi pengetahuan bahasa adalah Universal Grammar. UG adalah underlying principles yang berlaku untuk semua bahasa di seluruh muka bumi. UG adalah rumusan kebenaran bahasa yang memiliki posisi sebagai hukum tetap dan bersifat pasti. Sebagai sebuah hukum UG menentukan kebanaran yang pasti dantidakmengakomodasi versi-versi kebenaran yang lain. Ia menempati kutub bahasa yang berlaku universal dan memiliki ketetapan akan kepastian atau kebenaran. Bahasa yang unggul adalah bahasa yang berlaku universal dan pasti.

Keempat, relasi bahasa terhadap konteks. Rumusan bahasa Chomsky tidak mengakomodasi konteks di luar bahasa kognitif, objektif, logis, transparan dan universal. Bahasa yang tidak memuat ciri-ciri ini tidak akan terbaca oleh sistem bahasa yang bersifat alogaritmis-logis sehingga konteks bahasa tidak relevan. Dengan demikian model ini bersifat tertutup terhadap realitas di luar bahasa. Bahasa yang superior adalah bahasa yang tidak dibiaskan oleh konteks sosial.

Dari butir pembahasan di atas dapat disimpulkan nilai pengetahuan seperti apakah yang diusung dalam pemikiran Chomsky tentang bahasa. Pemikirannya menempati kutub nilai tertentu dan menempatkan ragam bahasa tertentu yang diposisikan superior. Nilai-nilai positif dalam teori bahasa adalah bahasa yang bersifat internal, mental, logis objektif, formal, netral, innate, pasti, transparan, universal, tetap, pasti, alogaritmis dan tertutup/akontekstual. Ciri-ciri seperti itu terdapat dalam bahasa yang berdiemnsi saintifik dan ilmiah sehingga bahasa yang superior adalah yang positivistik dan logis.

\section{Refleksi Nilai dalam Konstruk Teoritis Halliday}

Pertama, dalam gagasan Halliday objek linguistik adalah praksis penandaan bahasa. Bahasa yang dikaji adalah praksis bahasa sebagai proses interaksi sosial. Aspek praktis kebahasaan dinilai lebih positif ketimbang bahasa sebagai sesuatu yang diam di dalam kesadaran. Pengertian bahasa eksternal mengacu pada penandaan pengalaman terhadap dunia dan terhadap relasi sosial. Dengan demikian bahasa yang superior adalah bahasa sebagai sistem semiotik relasi sosial.

Kedua, subjek pengetahuan adalah manusia konkret yang terlibat dalam interaksi sosial. Subjek secara partisipatif membentuk dan dibentuk oleh msayarakat dimana bahasa itu digunakan. Subjek partisipatif adalah subjek kritis-interpretatif karena ia memaknai dan maknai oleh dunia. Bahasa yang superior adalah bahasa dinamis yang hidup di dalam masyarakat.

Ketiga, isi pengetahuan bahasa adalah metafungsi. Metafungsi ini mengacu pada sistem penandaan semiotik. Metafungsi adalah abstraksi fungsi bahasa, bukan abstraksi atas bahasa karena bahasa sebagai peristiwa komunikasi adalah otentik sehingga tidak dapat direduksi. Metafungsi di sini berperan sebagai device analitis. Sebagai piranti analitis, metafungsi ini mengakomodasi keberagaman makna dalam praktek diskursif. Pemaknaan atas bahasa merupakan kutub utamanya. Bahasa yang superior adalah bahasa yang otentik.

Keempat, realitas bahasa yang diambil Halliday adalah bahasa sebagai peristiwa komunikatif yang bersifat otentik. Bahasa bukan konstruk hampa baik dari sisi tatanan logika maupun tata bahasa. Bahasa membuka diri terhadap konteks sosial maupun kultural. Makna kontekstual ini memposisikan realitas sosial maupun kultural sebagai sumber makna yang tak terbatas. Dengan demikian aspek makna dalam bahasa terbuka terhadap realitas 
sosial dan kultural. Bahasa yang membuka diri terhadap kekayaan makna sosial dan kultural menempati posisi superior.

Dari konstruk teoritis pemikiran Halliday tampak bahwa nilai positif dari bahasa bersifat praksis, eksternal, semiotis, sosial, kultural, partisipatif, konkret, kritis, dinamis, diskursif, otentik, interpretatif dan terbuka. Ciri-ciri bahasa seperti ini terdapat dalam bahasa yang diguankan oleh ilmu-ilmu sosial-humaninora, budaya dan filsafat.

\section{SIMPULAN}

Dari butir pembahasan di atas dapat disimpulkan nilai pengetahuan seperti apakah yang diusung dalam pemikiran Chomsky tentang bahasa. Pemikirannya menempati kutub nilai tertentu dan menempatkan jenis bahasa tertentu yang diposisikan superior. Nilai-nilai positif dalam teori bahasa adalah bahasa yang bersifat internal, mental, logis objektif, formal, netral, innate, pasti, transparan, universal, tetap, pasti, alogaritmis dan tertutup/akontekstual. Ciri-ciri seperti itu terdapat dalam bahasa yang berdiemnsi saintifik dan ilmiah. Bahasa yang superior adalah yang positivistik dan logis.

Dari konstruk teoritis pemikiran Halliday tampak bahwa nilai positif dari bahasa bersifat praksis, eksternal, semiotis, sosial, kultural, partisipatif, konkret, kritis, dinamis, diskursif, otentik, interpretatif dan terbuka. Ciri-ciri bahasa seperti ini terdapat dalam bahasa yang digunakan oleh ilmu-ilmu sosial-humaninora, budaya dan filsafat.

Nilai terkait erat dengan pengalaman secara fundamental sebagai manusia. Konstruk teoritis Chomsky meletakkan relasi manusiabahasa seperti relasi manusia-benda dimana kemampauan rasional mencocokan diri dengan dengan suatu rumusan mutlak sebagai hukum bahasa yang pasti. Di sisi lain, Halliday meletakkan relasi manusia-bahasa seperti relasi manusia-manusia dimana konteks memainkan peran untuk membuka ruang tafsir atas makna.

\section{DAFTAR PUSTAKA}

Bakker dan Charris Z. (1990). Metodologi Penelitian Filsafat. Yogyakarta: Penerbit Kanisius.

Chomsky, N. (2006). Language and Mind. Cambridge: Cambridge University Press.

Grunberg, L. (2000). The Mistery of Values. Amsterdam: Rodopi.

Halliday. (1978). Language as Social Semiotic. London: Edward Arnold.

Hadi, H. (1991). Kebenaran dan Metodologi Penelitian Filsafat, sebuah Tinjauan Epistemologis (Makalah). Simposium Metodologi Penelitian Filsafat, Fakultas Filsafat UGM.

Hadi, H. (1994). Epistemologi, Filsafat Penetahuan. Yogyakarta: Penerbit Kanisius.

Hugh, P. McDonald. (2004). Radical Axiology: a First Philosophy of value. Amsterdam: Rodopi.

Kaelan. (2017). Filsafat Bahasa, Hakekat dan Realitas Bahasa. Yogyakarta: Paradigma.

Kvanvig L., Jonathan. (2003).The Value of Knowledge and the Pursuit of Understanding. Cambridge: Cambridge University Press.

Modrak, D. (2001). Aristotle's Theory of Language and meaning. Cambridge: Cambridge University Press

Peregrin, J. (2012). Linguistics and Philosophy. In: Ruth Kempson, Tim Fernando and Nicholas Asher (Eds), Philosophy of Linguistics. Amsterdam: North Holland. 


\title{
NILAI KEARIFAN LOKAL DALAM TUNJUK AJAR MELAYU KARYA TENAS EFFENDI
}

\author{
Marlina \\ Balai Bahasa Riau \\ emial: marlinabbpku@gmail.com
}

\begin{abstract}
(Title: The Value of Local Wisdom in “Tunjuk Ajar Melayu” by Tenas Effendi). This study aims at determining the value of local wisdom contained in the Tunjuk Ajar Melayu (Malay Guidance of Life) by Tenas Effendi. The main problem is what the values of local wisdom contained in the Tunjuk Ajar Melayu are. This study applied descriptive qualitative method. The primary data source is the Tunjuk Ajar Melayu contained in the book "Kesantunan dan Semangat Melayu (Politeness and Spirit of Malay)" by Tenas Effendi. The result of the research shows that Tunjuk Ajar Melayu contained local wisdom values which had to be maintained and preserved by the community owners. These values are having good intentions and good character, setting oneself in the harmonious position, positioning oneself smartly in certain situation and condition, being wise in considering and tolerating, willing to sacrifice and willing to yield, having humble heart, and maintaining good relations with neighbors. One way to maintain and preserve the values of local wisdom is to include the material of the Tunjuk Ajar Melayu as one of the local content of teaching materials in schools in Riau.
\end{abstract}

Keywords: Malay guidance of life, values, local wisdom

\section{PENDAHULUAN}

Kemajuan teknologi dan arus globalisasi mengakibatkan terjadinya krisis sosial. Krisis sosial telah menyebabkan manusia mengalami persaingan yang tidak sehat, korupsi, perang saudara, kemerosotan moral, dan terjadinya berbagai tindak kekerasan. Akibat langsung yang ditimbulkan adalah hilangnya nilai-nilai kemanusiaan, sehingga manusia pada gilirannya akan kehilangan akar tradisinya, bahkan identitas dirinya.

Arus modernisasi telah menyebabkan masyarakat terutama remaja mulai meninggalkan budaya lokal dan beralih ke budaya luar yang dianggap lebih mewakili diri mereka. Hal ini tentu berdampak pada perubahan gaya hidup dan pola pikir mereka sebagai seorang remaja. Muara dari semuanya adalah menurunnya kualitas moral para remaja.

Penurunan moral tersebut dapat dilihat dari meningkatnya angka kriminalitas di kalangan remaja, pemakaian narkoba yang telah sampai ke sekolah-sekolah, pergaulan bebas, pelecehan seksual, penganiayaan guru, hingga terjadinya pembunuhan di kalangan sesama remaja. Fenomena-fenomena ini tentu saja sangat memperihatinkan, mengingat bangsa Indonesia adalah bangsa yang beradab, beretika dan berbudi pekerti luhur.

Bangsa Indonesia sejatinya memiliki nilai-nilai karakter yang tercermin dari tradisi dan adat istiadat yang dimiliki oleh masyarakatnya. Nilai-nilai karakter inilah yang menjadi landasan moral dan menjadi pedoman hidup bagi masyarakat setempat. Nilai-nilai kehidupan inilah yang selanjutnya berkembang di dalam masyarakat dan dikenal sebagai sebuah kearifan lokal (Aji, 2019:2).

Oleh sebab itulah, nilai-nilai kearifan lokal ini harus kembali dihidupkan di kalangan remaja. Remaja dan generasi muda harus mengenal budaya dan tradisi yang ada di daerahnya. Seperti halnya dengan budaya Melayu. Budaya Melayu merupakan sebuah budaya yang sangat menjunjung tinggi nilai kesopansantunan, yang menjadi salah satu asas jati diri kemelayuan yang terpuji. Di dalam pergaulan sehari-hari sopan santun menjadi salah satu tolak ukur untuk menilai seseorang. 
Pentingnya kesopansantunan di dalam kehidupan orang-orang Melayu, menyebabkan mereka berusaha sepenuh daya dan upaya untuk menjadikan dirinya orang yang berbudi pekerti terpuji, berakhlak mulia dengan landasan iman dan takwa.

Berpegang kepada asas hidup dan menjunjung tinggi kesantunan menyebabkan orang Melayu ternama bukan hanya karena kekayaan alamnya yang melimpah, tetapi dikenal dan dihormati karena kesopan santunan, keterbukaan dan keramah-tamahannya. Itulah sebabnya nilai-nilai kesantunan diajarkan sejak dini, ditanamkan ke dalam hati anakanak mereka agar besarnya menjadi orang, yaitu menjadi orang yang santun, berbudi luhur, berakhlak mulia, elok lahirnya dan baik batinnya.

Di dalam kehidupan, manusia tidak dapat melepaskan dirinya dari kehidupan berumah tangga, bermasyarakat, berbangsa dan bernegara. Kehidupan itu memerlukan pergaulan, baik dalam ruang lingkup terbatas maupun terbuka dan luas. Karenanya, budaya Melayu memberikan tunjuk ajar tentang pergaulan itu, terutama dalam pergaulan bermasyarakat yang melibatkan banyak orang, suku dan bangsa. Orang tua-tua Melayu dengan segala kearifan dan kebijaksanaanya, telah berhasil menghimpun, menapis, mengayak dan membakukan nilai-nilai luhur yang mereka miliki, terutama dari sumber utamanya, yakni ajaran Islam. Nilai-nilai ini yang dilengkapkan dengan nilai-nilai budaya mereka yang Islami, dituangkan ke dalam bentuk tunjuk ajar, yang kemudian diwariskan secara turun temurun. Dengan nilai-nilai inilah mereka mampu mewujudkan kedamaian dan kesejahteraan dan kehidupan berumah tangga, bermasyarakat, berbangsa dan bernegara.

Tunjuk ajar Melayu mengandung berbagai nilai-nilai luhur yang dijadikan pedoman dan bekal hidup, terutama nilai-nilai luhur agama dan budaya yang islami. Nilai-nilai yang terdapat di dalam tunjuk ajar Melayu telah berurat berakar dalam kehidupan masyarakat Melayu pada zaman dahulu sehingga bisa dikatakan telah menjadi tradisi yang menaungi kehidupan masyarakatnya.
Di dalam kondisi yang benar dan konstruktif, nilai-nilai tradisi dapat membantu dinamika kehidupan masyarakat tempat nilainilai mendasar itu hidup dan berkembang, menumbuhkan dan mengembangkan integritas masyarakat, menciptakan solidaritas sosial, menumbuhkan kebanggaan akan identitas kelompok, dan berguna pula untuk mengukuhkan keharmonisan komunal. Oleh sebab itu, pada hakikatnya setiap masyarakat, baik masyarakat tradisionalmaupun masyarakat modern memerlukan nilai-nilai kehidupan yang didasari keyakinan atau kepercayaan atas hal-hal tertentu untuk mejalani perikehidupan bersama yang harmonis (WS, 2015: 199).

Nilai-nilai tradisi masyarakat Melayu ini disebut juga dengan nilai kearifan lokal. Kearifan lokal merupakan sebuah pengetahuan hasil proses adptasi komunikasi lokal dalam pengalaman hidupnya yang ditransformasikan secara turun temurun, dari satu generasi ke generasi berikutnya. Nilai kearifan lokal ini digunakan oleh masyarakat setempat dalam proses interaksi sosial kehidupan sehari-hari dengan alam dan lingkungan sosialnya sebagai bagian dari mekanisme untuk bertahan hidup (Fawziah, 2017: 96).

Kearifan lokal ini menyatu dalam sistem norma dan budaya yang diekspresikan dalam sistem budaya dan sistem sosialnya dan ditransmisikan melalui berbagai cerita-cerita berupa mitos, legenda, babad, suluk, tembang, hikayat, lontarak, dan lain sebagainya. Pada masyarakat Melayu Riau, salah satunya terdapat di dalam Tunjuk Ajar Melayu. Tunjuk Ajar Melayu ini dibukukan oleh Bapak Tenas Effendy di dalam buku yang berjudul "Kesantunan dan Semangat Melayu". Buku ini memberikan rambu-rambu tentang bagaimana seharusnya seorang anak Melayu bersikap dan berbuat di tengah-tengah masyarakat.

Nilai adalah segala sesuatu yang menarik bagi manusia sebagai subjek. Menurut Ridzal dalam (Herlina, 2014: 203), nilai adalah perasaan tentang apa yang diinginkan, ataupun apa saja yang boleh dan tidak boleh. Sedangkan menurut Bertends dalam (Herlina, 2014: 203), nilai merupakan sesuatu yang menarik bagi kita, sesuatu yang kita cari, sesuatu yang menyenangkan, sesuatu yang disukai dan 
diinginkan, atau bisa dikatakan sebagai sesuatu yang baik.

Kearifan lokal berasal dari dua kata, kearifan dan lokal. Kearifan (wisdom) bermakna pengetahuan yang berkenaan dengan penyelesaian suatu masalah untuk mewujudkan keseimbangan lingkungan dan keserasian sosial. Sedangkan istilah lokal berarti setempat (kawasan provinsi, kabupaten atau desa). Ketika berbicara tentang kearifan lokal yang akan terlintas di pikiran kita adalah sesuatu yang bersifat kelokalan/kedaerahan yang berasal dari zaman dahulu kala atau bisa juga dikatakan sebagai sesuatu warisan dari nenek moyang (Fawziah, 2017: 98).

Kearifan lokal merupakan gagasangagasan atau nilai-nilai, pandangan-pandangan setempat yang bersifat bijaksana, penuh kearifan, bernilai baik yang tertanam dan diikuti oleh anggota masyarakatnya. Untuk mengetahui suatu kearifan lokal di suatu wilayah maka kita harus memahami nilai-nilai budaya yang baik yang ada di dalam wilayah tersebut. Nilai kearifan lokal ini sebenarnya sudah diajarkan secara turun temurun oleh orang tua kepada anak-anaknya. Budaya gotong royong, saling menghormati dan tepa selera merupakan contoh kecil dari nilai kearifan lokal (Herlina, 2014: 203).

Menurut (Saddhono, 2017: 9) kearifan lokal dimaknai sebagai sebuah "perangkat" pengetahuan dan praktik-praktik yang dapat digunakan untuk menyelesaikan persoalan yang dihadapi dengan cara yang baik dan benar menurut masyarakat. Kearifan lokal merupakan sistem pengetahuan lokal yang dimiliki oleh masyarakat berdasarkan pengalaman dan petunjuk leluhurnya secara turun temurun, bersifat lentur untuk mengatasi situasi dan kondisi setempat terangkum dalam ekspresi verbal dan non-verbal untuk memperoleh ketenangan hidup bersama, manusiawi dan bermartabat. Pokok pikiran kearifan lokal meliputi ciri-ciri budaya, sekelompok manusia sebagai pemilik budaya, dan pengalaman hidup yang menghasilkan ciri-ciri budaya tersebut (Rahyono dalam Saddhono, 2017: 10).

Kearifan lokal memiliki ketahanan terhadap unsur-unsur yang datang dari luar dan mampu berkembang untuk masa-masa yang akan datang. Ketahanan kepribadian masyarakat dapat ditentukan oleh kekuatan kearifan lokal dalam menghadapi kekuatan dari luar, karena memiliki berbagai faktor strategis, yaitu pembentuk identitas sejak lahir, bukan keasingan bagi pemiliknya emosional masyarakat kuat kuat dalam penghayatan kearifan lokal, pembelajaran kearifan lokal tidak memerlukan pemaksaan, kearifan lokal mampu menumbuhkan harga diri dan percaya diri, kearifan lokal mampu meningkatkan masrtabat bangsa dan Negara (Saddhono, 2017: 10).

Kearifan lokal sebenarnya sangat berhubungan erat dengan kehidupan yang dijalani oleh manusia. Di mana kearifan lokal bisa tumbuh dan berkembang jika kehidupan manusia tetap berlangsung dan berjalan sebagaimana mestinya. Kearifan lokal bisa terus eksis di tengah dunia global jika manusia bisa menjaga budaya lokal dengan baik dan benar. Salah satu cara menjaga untuk menjaga kearifan lokal itu adalah melalui bahasa dan sastra (Disi, 2018: 5).

Sementara menurut Sultoni (2015: 231), kearifan lokal merupakan bentuk dialektika antara manusia dengan pengetahuan kehidupan. Pengetahuan yang diambil dari kehidupan di mana manusia itu berada kemudian direfleksikan untuk membantu manusia memaknai kehidupan. Sebagai pedoman masyarakat, selanjutnya kearifan lokal memberi panduan yang jelas ranahranah yang dapat dijangkau oleh tingkah laku manusia. Dalam proses terbentuknya, kearifan lokal tidak dikonsepsikan secara individu namun membutuhkan peran komunal yakni masyarakat. Selanjutnya kearifan lokal menjadi bagian dari budaya untuk kemudian menjadi identitas bahkan karakter suatu masyarakat. Karenanya, antara kearifan lokal dan budaya merupakan hubungan antara anak dengan induknya. Kearifan lokal tidak lain adalah bagian dari budaya suatu daerah.

Berdasarkan sifatnya, kearifan lokal dibedakan menjadi (a) verbal yang tercermin dalam kata-kata, klausa dan kalimat yang bersifat metaforis, dan (b) non-verbal yang tercermin dalam bahasa tubuh, berbagai simbol, lambang, gambar, dan sebagainya. Kearifan 
lokal dalam tunjuk ajar Melayu yang berupa kata-kata (verbal) yang mengilustrasikan cara yang ditempuh untuk mengatasi masalah hidup dapat bersifat biasa maupun metaforis. Oleh sebab itu, inti konteksnya

Nilai kearifan lokal dapat dimanfaatkan untuk menunjang pendidikan karakter karena dalam konsep kearifan lokal yang dimaksud dalam penelitian ini adalah segala nilai, baik nilai moral, nilai agama, nilai budaya dan nilainilai yang terdapat di dalam masyarakat yang diungkapkan di dalam Tunjuk Ajar Melayu karya Tennas Efendi.

Tennas Effendy (2006:2) mengungkapkan bahwa orang tua-orang tua Melayu mengingatkan, sebaik-baik manusia adalah mereka yang memiliki keseimbangan antara pengetahuan dan keimanan. Manusia yang memiliki keseimbangan ini lazim disebut manusia "sempurna" atau "orang bertuah" yang menjadi idaman setiap orang Melayu. Untuk mewujudkan manusia bertuah itu, orang Melayu mewariskan Tunjuk Ajar yang sarat dengan nilai-nilai luhur agama, budaya, dan norma-norma sosial.

Tunjuk ajar Melayu memiliki pengertian yaitu segala jenis petuah, petunjuk, nasihat, amanah, pengajaran dan contoh teladan yang bermanfaat bagi kehidupan manusia dalam arti luas. Menurut orang tua-orang tua Melayu, tunjuk ajar adalah segala petuah, amanah, suri tauladan, dan nasihat yang membawa manusia ke jalan yang lurus dan diridhoi Allah, yang berkahnya menyelamatkan manusia dalam kehidupan di dunia dan akhirat (Tennas Effendy, 2006).

Kedudukan Tunjuk Ajar Melayu sangat penting bagi orang Melayu karena kandungannya mencerminkan nilai-nilai luhur yang bisa dijadikan sebagai pedoman hidup dalam kehidupan sehari-hari. Tunjuk Ajar Melayu disampaikan kepada setiap generasi agar kehidupan masyarakat yang ada di bumi Melayu ini lebih terarah kepada kehidupan yang lebih baik. Pesan moral yang terdapat di dalam Tunjuk Ajar Melayu meliputi berbagai aspek kehidupan manusia seperti pesan kepada guru, orang tua, anak-anak, lingkungan, masyarakat, dan pemimpin. Pesan-pesan moral yang terkandung di dalam Tunjuk Ajar Melayu pada umumnya bersumber dari nilai-nilai dan syariat Islam. Hal ini menunjukkan bahwa orang Melayu memang dekat dengan islam. Segala sendi kehidupan masyarakat Melayu selalu mengacu kepada ajaran Islam.

Penelitian tentang Tunjuk Ajar Melayu telah banyak dilakukan oleh peneliti terdahulu. Di antaranya adalah "Analisis Nilai-Nilai Pendidikan Karakter dalam Buku Tunjuk Ajar Melayu Karya Tenas Effendy" (Raihaninur, 2019: 1-14). Penelitian ini menghasilkan kesimpulan bahwa buku Tunjuk Ajar Melayu mengandungdelapanbutirnilai-nilaipendidikan karakter yang dapat dijadikan sebagai acuan dalam pendidikan karakter di sekolah-sekolah. Nilai-niai pendidikan karakter tersebut adalah: religius, jujur, tanggung jawab, mandiri, kerja keras, peduli sosial, peduli lingkungan dan sahabat/komunikasi.

Masih menurut (Raihaninur, 2019: 13), dari ke 8 nilai-nilai pendidikan karakter tersebut, nilai religius merupakan nilai terbanyak yang terdapat di dalam Tunjuk Ajar Melayu. Hal disebabkan karena Melayu sangat erat kaitannya dengan agama Islam. Kehidupan masyarakat Melayu adalah kehidupan yang selalu berlandaskan kepada agama Islam.

Pada penelitian ini, penulis tertarik untuk mengangkat "Nilai Kearifan Lokal dalam Tunjuk Ajar Melayu" karya Tenas Effendi (Effendy, 2012). Penelitian difokuskan pada Kesantunan dalam Pergaulan. Penelitian ini dirasakan perlu karena saat ini Tunjuk Ajar Melayu sudah mulai diabaikan oleh masyarakat Melayu Riau. Hal ini disebabkan oleh kemajuan zaman dan pengaruh budaya luar yang begitu hebat menggempur budaya lokal. Akibatnya Tunjuk Ajar Melayu seolaholah hanya butir-butir kalimat yang terukir di dalam bukunya tanpa dihayati dan diamalkan lagi oleh masyarakat pemiliknya.

Oleh sebab itulah, penelitian tentang Tunjuk Ajar Melayu ini perlu dilakukan agar kembali menghidupkan ruh dan nilai-nilai yang terkandung di dalam Tunjuk Ajar Melayu. Tunjuk Ajar Melayu perlu dilestarikan karena Tunjuk Ajar Melayu memiliki banyak manfaat bagi masyarakat, yakni sebagai filter untuk menangkal arus globalisasi yang memporak porandakan mentalitas masyarakat dan 
berusaha memisahkan masyarakat dari nilainilai agama serta budaya.

Tunjuk Ajar Melayu dalam konteks menangkal budaya asing sangat terasa manfaatnya karena perbedaan tradisi antara budaya asing dengan budaya lokal. Budaya asing yang tidak kontekstual dengan adat dan tradisi kemelayuan, dapat dengan mudah diakses melalui berbagai teknologi informasi yang tersedia di mana pun, mulai dari ponsel, televisi, warnet, dan sebagainya.

\section{METODE}

Metode yang digunakan dalam penelitian ini adalah metode deskriptif kualitatif. Ratna (2012: 47) mengemukakan bahwa penelitian kualitatif memberikan perhatian terhadap data alamiah, data dalam hubungannya dengan konteks keberadaannya. Metode kualitatif melibatkan sejumlah besar gejala sosial yang relevan. Sesuai dengan namanya, penelitian kualitatifmempertahankan nilai-nilai. Sementara untuk sumber datanya adalah karya, naskah, data penelitian dan data formalnya adalah kata-kata, kalimat dan wacana.

Masih menurut Ratna (2012: 47-48), ciri terpenting metode kualitatif adalah: (1) Memberikan perhatian utama pada makna dan pesan, sesuai dengan hakikat objek, yakni sebagai studi kultural; (2) Lebih mengutamakan proses dibandingkan dengan hasil penelitian sehingga makna selalu berubah; (3) Tidak ada jarak antara subjek peneliti dengan objek peneliti, subjek peneliti sebagai instrumen utama, sehingga terjadi interaksi langsung antara keduanya; (4) Desain dan kerangka penelitian bersifat sementara sebab penelitian bersifat terbuka; (5) Penelitian bersifat alamiah, terjadi dalam konteks sosial budaya masingmasing.

\section{HASIL DAN PEMBAHASAN}

Masyarakat Melayu adalah masyarakat majemuk dengan kebudayaannya yang majemuk juga. Masyarakat Melayu memiliki budaya terbuka sehingga bumi Melayu ramai dikunjungi orang, sebagian menetap dan berbaur ataupun menyatu dengan orang
Melayu. Lambat laun. Terwujudlah masyarakat yang berasal dari berbagai kaum, suku, dan bangsa dengan latar budaya yang berbeda-beda. Untuk menyatukannya, diperlukan persamaan pandangan agar kemajemukan tersebut tidak menimbulkan perpecahan, bahkan sebaliknya bisa mendatangkan kerukunan dan kesejahteraan.

Salah satu alat pemersatu kemajemukan adalah melalui kesantunan. Sebab kesantunan dapat menimbulkan rasa saling hormat menghormati, harga menghargai, yang akan menghadirkan rasa kebersamaan dan persamaan. Puncaknya adalah terwujudnya rasa "senasib sepenanggungan, seaib dan semalu". Perpaduan inilah yang menjadi harapan setiap orang Melayu sehingga perbedaan latar suku dan budaya menyatu dalam kebersamaan yang rukun dan damai (Effendi, 2012: 85).

Tunjuk Ajar Melayu mengingatkan bahwa pergaulan hakikatnya untuk mewujudkan hubungan baik antara sesama manusia, membangun silaturrahim yang saling hormat menghormati, harga menghargai, kasih mengasihi, sehingga lahirlah masyarakat dan bangsa yang aman dan damai dan rasa kekeluargaan yang padu. Beberapa nilai kearifan lokal yang terdapat di dalam Tunjuk Ajar Melayu diuraikan sebagai berikut.

\section{Niat yang Lurus dan Sifat yang Elok Adat orang dalam bergaul Hatinya bersih berpalut iman Duduk beramai perangainya sopan Di sanalah banyak beroleh teman}

Pergaulan yang baik harus dilandasi niat yang baik juga. Niat yang baik berpangkal pada hati, jika hati bersih maka apa yang akan dilakukan juga akan menjadi bersih (baik). Hati yang bersih disebabkan karena memiliki iman yang kuat. Setelah membersihkan hati dan meluruskan niat maka bersikap dan berperilaku baik juga agar mendapatkan banyak teman. Seseorang yang memiliki sifat dan perilaku yang baik akan disenangi oleh banyak orang. Kemana pergi orang akan senang dan mau menerima dengan tangan terbuka. 
Wahai saudara dengar nasihat

Bergaul itu mencari sahabat

Kiranya jangan berniat jahat

Supaya hidup beroleh rahmat

Selain itu, dalam tunjuk ajar Melayu juga dinasihatkan agar dalam pergaulan jangan memiliki niat yang jahat kepada orang lain. Apalagi jika bersikap jahat. Niat dan sikap yang jahat akan membuat hidup tidak baik. Jika ingin hidup berkah dan mendapatkan rahmat, maka selalulah berbuat baik kepada orangorang di sekeliling kita. Sebab dalam ajaran agama, apa yang kita lakukan pada orang lain, semua itu akan berbalik kepada kita. Jika kita berbuat jahat, maka hal buruk juga yang akan menimpa kita. Sebaliknya jika kita melakukan hal-hal baik kepada orang lain, maka kebaikan juga yang akan kepada kita.

Bergaul jangan sampai mencari musuh. Cara agar bisa diterima dalam pergaulan dan mendapatkan teman adalah dengan selalu bersikap sopan dan santun. Sikap sopan dan santun akan mendatangkan rasa senang dan simpati dari orang-orang di sekeliling kita. Dengan sikap sopan dan santun juga, seseorang akan menjadi mulia.

\section{Wahai segala kaum kerabat \\ Bergaul itu luruskan niat \\ Jagalah diri pelihara tabi'at \\ Kemana pergi banyak sahabat}

\section{Tempatkan Diri pada yang Serasi}

Adat bergaul pada yang ramai

Tempatkan diri pada yang sesuai

Adat dijunjung lembaga dipakai

Supaya Nampak elok perangai

Adat bergaul dalam masyarakat

Tempatkan diri pada yang tepat

Arif membaca tanda isyarat

Bijak menengok kemahuan ummat

Supaya langkah tidak terdedat

Supaya pergaulan membawa manfaat

Agar dapat diterima di dalam pergaulan, seseorang harus bisa menempatkan diri dengan baik. Selain itu, jika ingin hubungan dengan orang sekitar menjadi baik dan harmonis, kita juga harus memperhatikan budaya dan adat istiadat yang ada di daerah Melayu. Dengan menjunjung adat istiadat yang ada di negeri Melayu ini maka secara tidak langsung hal itu akan menuntun sikap dan perilaku seseorang dalam bergaul. Sikap dan perilakunya akan menjadi elok. Dengan kata lain, adat istiadat bisa menuntun bisa menuntun masyarakat pemiliknya menjadi pribadi yang baik dan berakhlak yang mulia.

Hal lain yang juga perlu diperhatikan dalam bergaul adalah agar kita bisa mengerti dan memahami sikap dan perilaku orang-orang di sekitar kita. Apa yang mereka inginkan dan apa yang tidak mereka inginkan. Jika seseorang bisa memahami kehendak orangorang di sekitarnya, maka pergaulan akan terjalin dengan harmonis. Keharmonisan dalam pergaulan akan mendatangkan hikmah dan manfaat bagi masyarakat yang ada di dalam lingkungan pergaulan tersebut.

\section{Pandai-Pandai Membawa Diri}

Pandai-pandai membawa diri maksudnya adalah bersikap dan berperilaku baik dalam pergaulan. Orang Melayu memiliki budaya yang santun dalam pergaulan dengan teman, saudara, tetangga dan orang-orang disekitarnya. Kutipan Tunjuk Ajar Melayu mengajarkan agar dalam bergaul pandaipandailah membawa diri. Seperti kutipan di bawah ini.

\section{Wahai segala sahabat handai Bergaullah dengan elok perangai Supaya hidup rukun dan damai Saudara banyak sahabatpun ramai}

Budaya Melayu mengajarkan agar dalam bergaul seseorang harus memperhatikan sifat dan sikapnya kepada orang lain. Budi yang baik dan perangai yang elok menjadi modal utama dalam menciptakan hidup damai dan rukun dalam masyarakat. Selain itu, dengan kebaikan budi dan keelokkan perangai, seseorang akan disenangi banyak orang dan akan memiliki banyak sahabat. 
Wahai saudara ingatlah pesan Niatkan bergaul mencari teman Tunjukkan sikap santun dan sopan Supaya hidup beroleh kemuliaan

\section{Wahai saudara dengar amanah Dalam bergaul peliharalah lidah Dalam berkawan jagalah tingkah Orang suka sahabat bertambah}

Amanah berikutnya adalah agar seseorang selalu menjaga ucapan yang ke luar dari mulutnya. Jangan sampai ucapan kita menyinggung perasaan orang lain. Pepatah mengatakan, lidah terkadang lebih tajam dari sebilah pedang. Disebabkan ucapan, orang bisa berkelahi dan bermusuhan. Jika ucapan tidak dijaga maka akan menimbulkan perpecahan dan kekacauan. Selain menjaga ucapan, tingkah laku juga harus dijaga agar selalu baik. Apabila ucapan dan tingkah laku telah dijaga, maka orang-orang akan menyukai kita. Kita akan memiliki banyak teman dan sahabat. Hidup akan terasa lebih bermakna jika memiliki banyak teman dan sahabat.

\section{Bila bergaul mencari musuh Rumah tangga rusak kampung pun rusuh \\ Bangsa berpecah negeri pun rubuh Marwah tercampak, martabatpun runtuh}

Apabila seseorang tidak pandai bersikap dan berperilaku yang baik dalam pergaulan, maka bisa mengakibatkan kehancuran dalam berumah tangga. Misalnya, seorang istri atau suami tidak bersikap dan berperilaku baik kepada saudara dari suami atau istri, maka timbul permusuhuhan. Berawal dari permusuhan dengan keluarga suami atau istri, rumah tangga akan terancam. Hubungan tidak baik dengan keluarga suami atau istri tentu akan berdampak tidak baik juga ke dalam rumah tangga.

Selain itu, sikap dan perilaku yang tidak baik dalam pergaulan bisa membuat rusuh kampung yang ditempati. Apabila ada orang yang tersinggung karena ucapan dan sikap seseorang, maka bisa terpicu pertikaian antara kedua orang tersebut. Pertikaian ini bisanya juga dapat memicu pertikaian yang lebih luas. Sering terjadi pertikaian dan perkelahian antar kampung hanya karena ucapan satu orang. Disebabkan rasa tersinggung lalu yang lain merasa ingin membantu atau membela, maka timbullah pertikaian dan kerusuhan.

Pesan berikutnya yang terdapat di dalam tunjuk ajar Melayu adalah agar dalam bergaul seseorang memiliki niat yang baik, yakni untuk mendapatkan teman. Jangan sampai bergaul untuk mencari musuh. Cara agar bisa diterima dalam pergaulan dan mendapatkan teman adalah dengan selalu bersikap sopan dan santun. Sikap sopan dan santun akan mendatangkan rasa senang dan simpati dari orang-orang di sekeliling kita. Dengan sikap sopan dan santun juga, seseorang akan menjadi mulia.

\section{Wahai segala kaum kerabat \\ Bergaul itu luruskan niat \\ Jagalah diri pelihara tabi'at \\ Kemana pergi banyak sahabat}

Dalam bergaul juga harus menjaga diri dan menjaga tabiat. Yakni menjaga sikap dan perilaku dengan orang-orang di sekeliling kita. Sikap dan perilaku kita jangan sampai membuat orang marah dan tersinggung. Dalam ajaran agama, semua ini disebut sebagai akhlak yang mulia. Seseorang yang memiliki akhlak mulia akan disukai oleh orang-orang di sekelilingnya dan tentu akan mendapatkan banyak teman dan sahabat.

\section{Arif Menimbang Bijak Menenggang}

Pergaulan memerlukan kearifan untuk menjaga dan menenggang perasaan orang lain, menjaga hati orang dan memahami isi hatinya. Hubungan pergaulan dengan orang lain akan berjalan dengan baik jika kita bisa menjaga perasaan orang lain agar tidak tidak tersinggung. Selain itu, hubungan dengan orang lain juga akan berlangsung dengan baik jika kita tidak membuat aib dan malu, tidak 
membangkitkan ketidaksenangan apalagi kemarahan orang lain.

\section{Adat bergaul yang kita pegang Arif menimbang bijak menenggang Bercakap jangan sembarang-barang Berbuat jangan menyinggung orang Jangan melanggar pantang dan larang Jangan berbuat sewenang-wenang Jangan mengaib memalukan orang Jangan bergaya lagak temberang Supaya bergaul semuanya senang Hidup beramai terasa lapang}

Banyak hal yang diajarkan di dalam Tunjuk Ajar Melayu. Bahwa dalam bergaul kita harus bijak menimbang dan menenggang. Kita tidak boleh berbicara sembarangan yang bisa menyinggung perasaan orang lain. Budaya Melayu sangat memperhatikan tentang hal ini, yaitu dalam menjaga perasaan orang lain.

Begitu juga dengan pantang larang. Setaip daerah di nusantara ini tentu memiliki pantang dan larang yang harus diketahui oleh masyarakatnya. Tunjuk Ajar Melayu mengingatkan agar kita, masyarakat Melayu, jangan sampai melanggar pantang larang yang terdapat di bumi Melayu. Apa yang tidak dibolehkan, jangan dilakukan. Sebab sesuatu yang telah dipantangkan atau dilarang oleh para orang tua kita dahulu tentulah karena ada alasannya.

Tunjuk Ajar Melayu juga mengajarkan agar seseorang bisa menjaga aib dan malu saudara-saudaranya. Kita dilarang untuk membuka aib orang lain. Sebab membuka aib saudara kita sama juga dengan membuka aib sendiri. Hal ini sama dengan yang diajarkan di dalam agama Islam.

Jika beberapa hal tersebut bisa dilakukan, maka kehidupan bermasyarakat akan menjadi tenang dan damai. Akan terjalin hubungan yang baik satu dengan yang lainnya. Semua akan merasa senang dan bahagia, karena tidak akan timbul masalah dalam pergaulan sehari-hari. Hidup bersama itu akan terasa indah dan lapang.
Rela Berkorban Mau Mengalah

Rela berkorban jadikan sifat

Supaya bergaul banyak sahabat

Kerugian diri jangan diingat

Supaya yang jauh menjadi dekat

Supaya yang renggang menjadi rapat

Hidup beramai manfaatnya dapat

Orang sayang banyaklah berkat

Adat bergaul mahu mengalah

Berlapang dada menjauhi masalah

Berserah diri kepada Allah

Supaya bergaul membawa berkah

Tunjuk ajar Melayu juga mengajarkan tentang adat dalam bergaul, yakni tidak menang sendiri dan mau mengalah. Hal ini sesuai dengan budaya Melayu dan juga dengan budaya bangsa Indonesia. Sebab dalam butir-butir Pancasila terdapat tentang tenggang rasa dan tepa selera. Tenggang rasa dan tepa selera akan membuat kehidupan bermasyarakat menjadi tentram dan damai. Selain itu, adab dalam bergaul adalah berlapang dada dan menjauhi masalah. Sabar dalam menghadapi persoalan kehidupan yang menimpa diri kita serta sabar dalam menghadapi sikap dan perilaku teman, sahabat, maupun sanak saudara. Sebab setiap orang memiliki sifat dan perilaku yang berbeda. Tidak tertutup kemungkinan sikap dan perilaku teman atau sahabat kita itu tidak berkenan di hati. Akan tetapi kita harus menerima sikap dan perilaku teman atau sahabat kita itu dengan sabar agar tidak timbul permasalahan dengan mereka.

Tunjuk ajar Melayu juga mengingatkan agar kita sebagai hamba Allah menyerahkan diri dan memasrahkan diri hanya kepada Allah semata. Dengan menghadirkan Allah dalam setiap urusan hidup kita, maka semua akan menjadi berkah dan bermakna. Begitu juga dalam persahabatan dan pergaulan dengan sesama manusia. Bergaul dan bersahabatlah karena Allah agar persahabatan tersebut membawa berkah.

\section{Rendahkan Hati}

Elok bergaul merendahkan hati Jauhkan sifat tinggi meninggi 


\section{Berlagak sombong jangan sekali Supaya bergaul tidak terkeji}

Hal berikutnya yang diajarkan dalam Tunjuk Ajar Melayu adalah agar dalam bergaul bisa bersikap merendahkan hati. Kita tidak boleh bersikap sombong dengan apa yang dimiliki, karena tidak ada orang yang suka dengan teman yang sombong. Akan tetapi, jika kita rendah hati, banyak orang yang akan menyukai kita. Banyak orang yang akan nyaman berteman dan bersahabat dengan kita. Oleh karena itu, sangat penting untuk menjaga hati. Agar tidak sombong dan tinggi hati. Sikap sombong merupakan penyakit yang akan mengotori pergaulan dan persahabatan.

\section{Berendah hati banyak manfaat Dalam bergaul orang kan hormat Saudara suka sahabat mendekat Hidup beramai semakin erat Manfaatnya dapat dunia akhirat}

Tunjuk Ajar Melayu mengajarkan agar kita menjadi orang yang rendah hati. Orang yang rendah hati akan disukai oleh orang lain. Orang akan lebih hormat kepada orang yang memiliki sifat rendah hati. Sebaliknya orang sangat membenci orang yang bersifat sombong dan angkuh. Jika kita rendah hati, maka akan banyak sahabat yang akan mendekat kepada kita. hubungan dengan orang-orang di sekitar akan menjadi harmonis. Allah juga sangat menyukai orang yang rendah hati. Di dalam Alquran dikatakan tidak akan masuk surga orang yang di dadanya terdapat sifat sombong. Oleh sebab itu, berhati-hatilah terhadap sifat tercela yang satu ini.

Bisa dikatakan, sifat rendah hati memiliki manfaat dunia dan akhirat. Agar kita bisa memiliki sifat rendah hati, maka janganlah merasa kita yang paling hebat. Jangan meremehkan dan menganggap rendah orang lain.

\section{Menjaga Hubungan Baik dengan Tetangga}

Tidak dapat dipungkiri, kita hidup dalam keompok-kelompok masyarakat yang disebut dengan tetangga. Tetangga merupakan orang terdekat yang selalu berhubungan dengan kita dalam kehidupan sehari-hari. Tetangga juga yang akan selalu ada jika kita memerlukan bantuan dan pertolongan. Tetangga akan menjadi orang pertama yang hadir jika kita ditimpa musibah atau kemalangan. Oleh sebab itu, kita memang dianjurkan untuk bersikap dan berhubungan baik dengan para tetangga. Seperti yang terdapat di dalam Tunjuk Ajar Melayu berikut ini.

\section{Dengan tetangga baikkan laku Sakit senang bantu membantu Tetangga datang bukakan pintu Bertegur sapa janganlah jemu}

Adab bertetangga tidak hanya diatur dalam agama, tetapi dalam budaya Melayu juga menjadi perhatian penting. Dari kutipan Tunjuk Ajar Melayu di atas, kita diharapkan untuk bersikap baik pada tetangga. Saudara terdekat adalah tetangga. Jika kita sakit atau mendapatkan kemalangan, maka yang akan lebih duluan tahu dan datang membantu tentulah tetangga di kiri dan kanan kita. Begitu juga untuk hal-hal suka ria, tetangga terdekat juga yang akan lebih duluan membantu. Oleh sebab itu, kita harus bersikap baik kepada tetangga. Susah dan senang harus saling membantu. Apabila tetangga datang bertamu ke rumah, kita harus menyambutnya dengan baik dan ramah. Jangan pernah bosan bertegur sapa dengan tetangga. Kita harus selalu menjaga silaturahmi dan hubungan baik dengan mereka.

\section{Dengan jiran beramah tamah Jangan sekali fitnah menfitnah Jangan berkira senang dan susah Salah sedikitjangan berbantah}

Selain bersikap baik dan ramah tamah kepada tetangga, hal yang paling tidak dibolehkan dalam bertetangga adalah saling menfitnah. Fitnah dan adu domba akan merusak hubungan dengan para tetangga. Oleh sebab itu, seperti yang telah diungkapkan sebelumnya, kita harus menjaga ucapan dan lisan dengan baik. Agar tidak ada yang tersinggung oleh 
ucapan kita. Sekali saja orang tersinggung oleh ucapan kita, maka akan sulit untuk mengambil hati mereka kembali. Hubungan yang terlanjur memburuk akibat ucapan yang tidak baik akan sulit diperbaiki lagi.

\section{Dengan tetangga maaf memaafkan Kesalahan kecil jangan dibesarkan Aib dan malu jangan didedahkan Kelemahan orang jangan disingkapkan}

Kehidupan bertetangga diatur dengan baik di dalam ajaran agama Islam, begitu juga di dalam adat istiadat dan budaya Melayu. Tidak bisa dipungkiri, saudara terdekat kita adalah tetangga. Ketika seseorang berada dalam kondisi senang, bahagia, sulit, menderita sakit ataupun kemalangan, tetangga terdekatlah yang lebih dulu tahu. Tetangga juga yang akan lebih dulu datang membantu. Oleh sebab itu, kita diajarkan untuk berbuat baik kepada tetangga, saling maaf memaafkan jika ada salah dan kilaf.

Satu hal yang tidak boleh dilakukan adalahsalingmembukaaibataumengungkapkan kesalahan dan kekurangan tetangga. Sebagai seorang manusia, tetangga tentu tidak luput dari kesalahan dan kekilafan. Janganlah kesalahan tetangga menjadikan alasa permusuhan dan menimbulkan benci dan dendam. Apapun kelemahantetangga sebaiknya disimpan sendiri, jangan diungkapkan kepada orang lain. Sebab Islam mengajarkan, membuka aib saudara kita sama dengan membuka aib sendiri. Sementara tetangga adalah saudara terdekat kita.

\section{Dengan tetangga berunjuk beri Jangan mementingkan diri sendiri Mana yang hilang sama dicari Mana yang susah sama disantuni}

Kutipan tunjuk ajar Melayu di atas mengingatkan agar dalam hidup bertetangga saling memberi dan menerima. Bagi siapa yang memiliki kelebihan harta, maka berbagilah dengan para tetangga. Dalam hidup bermasyarakat, kita tidak bisa mementingkan diri sendiri. Oleh karena manusia adalah makhluk sosial yang saling membutuhkan satu sama lain. Jika tetangga kesusahan, kita harus siap membantu. Sebab jika kita kesusahan tentu tetangga juga yang akan datang membantu.

\section{SIMPULAN}

Tunjuk Ajar Melayu mengandung nilai-nilai kearifan lokal negeri Melayu. Nasihat, petuah, dan budaya yang terkandung di dalamnya bisa dijadikan sebagai rambu-rambu dalam menghadapi kehidupan bermasyarakat, baik di bumi Melayu maupun di negeri orang. Oleh sebab itu, Tunjuk Ajar Melayu dapat dijadikan sebagai bahan pembelajaran bagi siswa dan pelajar di sekolah. Hal ini bisa dilakukan dengan memasukkan Tunjuk Ajar Melayu sebagai salah satu materi muatan lokal di SD, SMP dan SMA.

Berdasarkan penjabaran hasil analisis dapat disimpulkan bahwa Tunjuk Ajar Melayu yang memberikan petunjuk tentang kesantunan dalam pergaulan memiliki beberapa nilai kearifan lokal Melayu, di antaranya yaitu: 1) Luruskan niat dan elokkan sifat, 2) tempatkan diri pada yang serasi, 3) Pandai-pandai membawa diri, 4) Arif menimbang, bijak menenggang, 5) Rela berkorban dan mau mengalah, 6) Rendahkan hati, 7) Menjaga hubungan baik dengan tetangga.

Nilai kearifan lokal yang terkandung di dalam Tunjuk Ajar Melayu memberikan petunjuk kepada masyarakat Melayu dalam hal bersikap, bergaul, dan bermasyarakat. Tunjuk Ajar melayu mengajarkan tentang kesopanan, beradat, tahu malu, sadar diri, cukup ajar, berbudi pekerti, berbudi bahasa. Hal inilah yang harus diajarkan kepada anakanak semenjak mereka kecil, dengan harapan akan mereka gunakan sampai mereka dewasa, hingga akhir hayat mereka.

Penanaman nilai kesantunan ke dalam diri anak-anak tentu harus melalui proses pendidikan dan pembelajaran yang panjang yang dimulai sejak dini sampai sepanjang hayatnya. Kearifan orang Melayu untuk mengekalkan kesopan santunan, melahirkan butir-butir tunjuk ajar yang sarat makna dan dapat dijadikan pegangan dan arahan dalam mendidik dan mengajar anak-anak. 


\section{DAFTAR PUSTAKA}

Aji, M. S. (2019). Kearifan Lokal dalam Novel Dawuk Karya Mahfud Ikhwan serta Relevansinya sebagai Materi Pembelajaran Sastra di SMA. Universitas Sebelas Maret Surakarta.

Disi, L. (2018). Pembelajaran Bahasa dan Sastra Berbasis Kearifan Lokal sebagai Upaya Optimalisasi Pendidikan Karakter Menuju Dunia Global. Jurnal Pembelajaran Bahasa dan Sastra Indonesia, 8, 1-9.

Effendy, T. (2006). Tunjuk Ajar Melayu. Yogyakarta: Balai Kajian dan Pengembangan Budaya Melayu.

Effendy, T. (2012). Kesantunan dan Semangat Melayu. Malaysia: Akademi Pengajian Melayu Universiti Malaya.

Fawziah. (2017). Nilai Karakter dan Nilai Kearifan Lokal dalam Karya Sastra: Apresiasi Sastra dalam Kumpulan Cerpen Bertanya Kerbau pada Pedati. Andragogi Jurnal Diklat Teknis, V, 95-115.

Herlina. (2014). Nilai Kearifan Lokal dalam Novel Negeri Sapati Karya Laode. M. Insan Sebagai Pendukung Pelaksanaan Pendidikan Karakter. Jurnal Pendidikan Bahasa, V0l 3, 201-210.

Raihaninur, S. dkk. (2019). Analisis NilaiNilai Pendidikan Karakter dalam Buku Tunjuk Ajar Melayu Karya Tenas Effendy. JOM FKIP UNRI, Vol 6,1-14.
Saddhono, K. (2017). Membangun Kearifan Lokal Melalui Karya Sastra dan Budaya Daerah (Jawa). In Seminar Nasional Bahasa dan Budaya (hal. 8-17). Denpasar: Jurusan Pendidikan Bahasa dan Sastra Agama, Fakultas Dharma Acarya, Institut Hindu Dharma Negeri Denpasar.

Sultoni, A. (2015). Pembelajaran Sastra Berbasis Kearifan Lokal sebagai Upaya Optimalisasi Pendidikan Karakter Kebangsaan Menuju Masyarakat Ekonomi Asean (MEA). In Seminar NasionalPendidikan Bahasa Indonesia (hal. 229-236).

WS, H. (2015). Lokal dalam Tradisi Lisan Kepercayaan Rakyat Ungkapan Larangan tentang Kehamilan, Masa Bayi, dan Kanak-Kanak Masyarakat Minangkabau Wilayah Adat Luhak Nan Tigo. Kembara, Vol 1, 198-204. Diambil dari http://ejournal.umm. ac.id/index.php/kembara/index 